\title{
Assessment of Dairy Cattle Production, Handling and Marketing Systems of Milk and Milk Products in Bako Tibe District of West Showa Zone, Ethiopia
}

\author{
Miressa Benti $^{1, *}$, Sintayehu Yigrem ${ }^{2}$, Temesgen Jembere ${ }^{3}$ \\ ${ }^{1}$ Department of Animal Production, Bako Agricultural Polytechnic College, Bako, Ethiopia. \\ ${ }^{2}$ School of Animal and Range Sciences, College of Agriculture, Hawassa University, Hawassa, Ethiopia. \\ ${ }^{3}$ Holeta Agricultural Research Centre, Holeta, Ethiopia.
}

How to cite this paper: Miressa Benti, Sintayehu Yigrem, Temesgen Jembere. (2021) Assessment of Dairy Cattle Production, Handling and Marketing Systems of Milk and Milk Products in Bako Tibe District of West Showa Zone, Ethiopia. International Journal of Food Science and Agriculture, 5(3), 538-549.

DOI: 10.26855/ijfsa.2021.09.026

Received: July 12, 2021

Accepted: August 8, 2021

Published: September 14, 2021

*Corresponding author: Miressa Benti, Department of Animal Production, Bako Agricultural Polytechnic College, Bako, Ethiopia.

Email: miressab91@gmail.com

\begin{abstract}
The objective of the study was to assess the dairy cattle production, handling and marketing systems of milk and milk products. Primary data was collected from 150 sample dairy cattle producers, multiple key informants and group discussions. Data were analysed by using descriptive statistics and SPSS (Statistical Package for Social Science) version 20. The study district was stratified in to three based on agro-ecological differences as lowland, midland and highlands. Result of the study showed that the dairy cattle a production practice that prevails in the district is mainly mixed crop-livestock. Shortage of land and inefficient breeding services were ranked as main challenges while year round availability of water, absence of cultural prohibition and high demand of dairy products consumption were mentioned as important dairy farming opportunities in the area. Grazing natural pasture and cereal crop residues were mentioned as main feed resources for dairy cattle. Average lactation length for indigenous and crossbreds were: $7.3 \pm 0.09$ and $9.00 \pm 0.6$ months, respectively. The averages daily milk off-take of indigenous cows during wet and dry seasons respectively was (litre/cow) (1.7 \pm 0.1$)$ and (1.5 \pm 0.03$)$; whereas those of crossbreds were $6.5 \pm 0.1$ and $5 \pm 0.6$ ). The average age at first service identified for local and crossbreds' heifers were $44.5 \pm 0.2$ and $29 \pm 0.3$ months respectively. The average age at first calving for local and crossbreds in the study area were: $54.5 \pm 0.2$ and $38.4 \pm 0.5$ months respectively. The overall average calving interval reported for local and crossbreds' dairy animals were $16.6 \pm 0.2$ and $14.2 \pm 0.8$ months respectively. Plastic containers are important utensils figured for dairy products handling. The study concluded that dairy cattle production in the area is not improved, as only few crossbreeds prevail, shortage of grazing lands, health problems and lack of working capital are some of the major reasons for poor performance of dairy cattle production. Based on the result, extension services, awareness creation, trainings and intensive work should be developed as well as dairy value chain is needed to develop and promote the sub-sector.
\end{abstract}

\section{Keywords}

Dairy cattle production, Handling, Milk and milk products 


\section{Introduction}

Ethiopia is believed to have the largest livestock population in Africa with more than 60 million cattle, 31 million sheep, 30 million goats, 2 million horses, 8 million donkeys, 0.4 million mules, and about 1 million camels [1]. In spite of such a substantial livestock population, the dairy sector is not developed to the expected level. The poor genetic potential for productive traits, in combination with the sub-standard feeding and management practices are the main contributors to the low productivity [2].

The major species used for milk production in Ethiopia are cattle, camel and goats. Cattle produce $83 \%$ of the total milk and $97 \%$ of the cow milk comes from indigenous cattle breeds [3]. But, production per animal is extremely low and the lactation milk yield for the indigenous cows was reported to range from 494 to $850 \mathrm{~kg}$ under optimum management [4].

The annual milk production in Ethiopia is estimated to be 3.1 billion litres from cattle and the average milk yield per cow per day at country level is about 1.4 litres [5]. However, the per capita milk consumption was estimated to be 19.2 $\mathrm{kg}$ total [6]. Moreover, selection for high milk production within these indigenous cattle would require a long-term genetic improvement program [7].

The Oromia national regional state is the largest cattle populated region in the country. It is the home of 24,144,361 cattle [1]. In spite of this huge resource, little work has been done about dairying in the region. Lack of management in relation to feeds and feeding, healthcare, housing and watering were which may lower the performance of dairy cattle production practices. Hence, the producer may not get reasonable benefit from their dairy activity unless appropriate improvement strategies have to be introduced. In order to meet the need of producers, it is essential to explore the existing dairy cattle production, handling practices of milk and milk products, analyse challenges and opportunities of dairy production for sustainable dairy development in the area.

\section{Materials and Methods}

The study was carried out at Bako Tibe district which is located at about $251 \mathrm{~km}$ West of Addis Ababa. It is located at $8^{\circ} 55^{\prime} 18^{\prime \prime}$ to $9^{\circ} 14^{\prime} 13^{\prime \prime} \mathrm{N}$ latitude and $37^{\circ} 01^{\prime} 54^{\prime \prime}$ to $37^{\circ} 17^{\prime} 07^{\prime \prime} \mathrm{E}$ longitude and an altitude range of $1,570-2,600$ masl. The total area of the district is about $645 \mathrm{~km}^{2}$. The total population size of the district is 133,584 as living as 22,880 total household heads [8]. The district comprises 28 peasant associations and 4 urban kebeles.

The dominant agro-ecologies zone of the study area is low-lands covering $51 \%$, midland covering $37 \%$ and highland accounting $12 \%$ with bimodal rain fall characteristics. The area receives an average of $1,242 \mathrm{~mm}$ rain fall annually and the temperature ranges from 13.3 to $27.9^{\circ} \mathrm{C}$. The area is characterised by mixed farming system, where cattle $(148,878)$, sheep $(13,531)$, goats $(15,381)$, chicken $(106,738)$, horses $(3,947)$, donkeys $(9,106)$ and mules $(1,096)$ are raised along crops. The major crops grown in the area are maize (dominant), teff, pepper, sweet potato, haricot bean, noug, barley, wheat, sorghum, mango, banana and sugarcane [9].

\subsection{Determination of sample size and sampling procedure}

The target population was all households who had lactating dairy cattle. The sample size was determined using the formula recommended by [10] for survey studies. $\mathrm{N}=0.25 /(\mathrm{SE})^{2}$ Where: $\mathrm{N}=$ Sample size, $\mathrm{SE}=$ Standard error with $95 \%$ confidence level. With the assumption of $4 \%$ standard error the research study was used a total of 150 farm households as sample units.

The district has 32 kebeles and three agro-ecological zones, and then the kebeles were stratified in to three based on the agro-ecological differences. For the study, three kebeles were selected randomly from 32 kebeles in which one kebele low land, mid land and highland. The sample respondents from each kebeles were selected by random sampling technique among from a list of farmers registered as milk producers of the respective kebeles. Based on the above information, Proportional to sample size method was applied to distribute the total sample size across the selected kebeles.

\subsection{Data analysis}

Data were analysed by using descriptive statistics such as mean and standard error, percentage and frequency. Statistical analysis of the primary data was made using the SPSS (Statistical Package for Social Science) version 20. Challenges and opportunities of dairy production systems; milk utilization and income sources were analyzed and summarized by index method. Index was computed with the principle of weighted average according to the following formula as employed by [11]:

Index $=\mathrm{R}_{\mathrm{n}} * \mathrm{C}_{1}+\mathrm{R}_{\mathrm{n}}-1 * \mathrm{C}_{2}+\ldots .+\mathrm{R}_{1} * \mathrm{C}_{\mathrm{n}} / \sum \mathrm{R}_{\mathrm{n}} * \mathrm{C}_{1}+\mathrm{R}_{\mathrm{n}-1} * \mathrm{C}_{2} \ldots . \mathrm{R}_{1} * \mathrm{C}_{\mathrm{n}}$ Where;

$\mathrm{R}_{\mathrm{n}}=$ Value given for the least ranked level (example if the least rank is 5th rank, then

$\mathrm{R}_{\mathrm{n}}=5, \mathrm{R}_{\mathrm{n}-1}=4$ and $\left.\ldots \mathrm{R}_{1}=1\right)$.

$\mathrm{C}_{\mathrm{n}}=$ Counts of the least ranked level (in the above example, the count of the $5^{\text {th }}$ rank $=C n$, and the counts of the $1^{\text {st }}$ 
rank $=\mathrm{C} 1)$.

\section{Results and Discussion}

\subsection{Livestock herd size and population trends}

The overall present average ( \pm SE) Tropical Livestock Unit (TLU) numbers per household for the study area was shown in Table 1. The figure indicated that the average population of cattle and chickens were greater than the average population of small ruminants and equines in the study areas. The overall average cattle per household heads' in the current study were less than the previous finding reported by [12] that the average cattle holding per household in central highlands of Ethiopia was 8.6 \pm 0.8 . The lower cattle holding per household observed here may be related to management situation and farming practices which may effect on the cattle population.

When the preceding livestock quantity compared with the present time, majority of them (79.3\%) mentioned that the trend of their livestock number has been decreasing. This was due to several reasons discussed by group participants that might include diseases and parasites, lack of knowledge, poor access to inputs and services, lack of credit services and shortage of land because of expansion of crop cultivation. Institute of Biodiversity Conservation (IBC) [13] reported that indigenous cattle breeds populations were at decreasing trend due to feed shortage as a result of degradation grazing areas, expansion of crop cultivation and trypanosomosis.

Table 1. Average ( \pm SE) current tropical livestock unit (TLU) and composition per HHs in the study area

\begin{tabular}{ccccc}
\hline \multirow{2}{*}{ Livestock Composition } & $\begin{array}{c}\text { Lowland N=58 } \\
\text { Mean } \pm \text { SE }\end{array}$ & $\begin{array}{c}\text { Midland N=50 } \\
\text { Mean } \pm \text { SE }\end{array}$ & $\begin{array}{c}\text { Agro-ecology } \\
\text { Highland N=42 } \\
\text { Mean } \pm \text { SE }\end{array}$ & $\begin{array}{c}\text { Overall Mean (N=150) } \\
\text { Mean } \pm \text { SE }\end{array}$ \\
\hline Cattle & $5.1 \pm 0.9$ & $5.3 \pm 0.8$ & $5.1 \pm 0.8$ & $5.2 \pm 0.5$ \\
Small ruminants & $0.3 \pm 0.3$ & $0.31 \pm 0.3$ & $0.28 \pm 0.4$ & $0.3 \pm 0.2$ \\
Equines & $0.66 \pm 0.2$ & $0.67 \pm 0.1$ & $0.67 \pm 0.1$ & $0.67 \pm 0.1$ \\
Chickens & $0.06 \pm 0.4$ & $0.07 \pm 0.4$ & $0.05 \pm 0.4$ & $0.06 \pm 0.2$ \\
\hline
\end{tabular}

$\mathrm{N}=$ Number of respondents, $\mathrm{SE}=$ Standard error

\subsection{Cattle herd structure}

The average numbers (SE) of indigenous and cross breed cattle owned by respondents in the study area were shown in Table 2. The result revealed that the majority of the cattle in study area are indigenous cattle. The outcome is in consistent with [14] reported that about $98 \%$ of the total cattle population was indigenous cattle population, $1.6 \%$ of the cattle populations in Ethiopia were crossbred and 0.2\% exotic cattle. Similarly, [15] also reported that the majority of dairy cows were indigenous animals, which have low milk production performances in Bako Tibe district, West showa, Ethiopia.

The average number of lactating cows per household in this study is similar to other nearby districts as reported by [16]. In the study area, crossbred dairy types are not commonly owned by farmers, especially in the mid- and highlands. Relatively more crossbred cows are owned by farmers in the low lands, which makes the study area unique from this aspect.

Table 2. Cattle herd size (Mean \pm SE) owned at HHs and according to agro-ecological differences

\begin{tabular}{ccccc}
\hline Cattle type & Lowland N=58 \\
Mean \pm SE & $\begin{array}{c}\text { Midland N=50 } \\
\text { Mean } \pm \text { SE }\end{array}$ & $\begin{array}{c}\text { Agro-ecology } \\
\text { Highland N=42 } \\
\text { Mean } \pm \text { SE }\end{array}$ & $\begin{array}{c}\text { Overall Mean (N=150) } \\
\text { Mean } \pm \text { SE }\end{array}$ \\
\hline Indigenous & $1.1 \pm 0.1$ & $1.2 \pm 0.1$ & $1.4 \pm 0.1$ & $1.3 \pm 0.1$ \\
Lactating cow & $0.6 \pm 0.1$ & $0.3 \pm 0.1$ & $0.5 \pm 0.1$ & $0.5 \pm 0.1$ \\
Dry cow & $1.3 \pm 0.1$ & $1.2 \pm 0.1$ & $1.4 \pm 0.1$ & $1.3 \pm 0.1$ \\
Calves<1year & $0.8 \pm 0.2$ & $1.2 \pm 0.2$ & $1.2 \pm 0.2$ & $1.03 \pm 0.1$ \\
Heifers & $0.7 \pm 0.1$ & $0.6 \pm 0.1$ & $0.5 \pm 0.1$ & $0.6 \pm 0.1$ \\
Bulls & $2.2 \pm 0.2$ & $2.7 \pm 0.2$ & $2.2 \pm 0.3$ & $2.2 \pm 0.1$ \\
Oxen & & & - & $0.03 \pm 0.02$ \\
Crossbred & $0.1 \pm 0.1$ & - & - & $0.01 \pm 0.01$ \\
Lactating cow & $0.03 \pm 0.02$ & - & - & $0.03 \pm 0.02$ \\
Dry cow & $0.1 \pm 0.1$ & - & $0.03 \pm 0.02$ \\
Calves less than 1year & $0.1 \pm 0.1$ & - & & \\
Heifers & & & & \\
\hline
\end{tabular}

$\mathrm{N}=$ Number of respondents, $\mathrm{SE}=$ Standard error 


\subsection{Challenges and opportunity of dairy cattle production}

\subsubsection{Challenges of dairy cattle production}

The major challenges of dairy production in the study area were ranked according to the respondents (Table 3). The result prevails that shortages of land for grazing or forage development in the area were ranked as the first most important challenges of dairy cattle production in the surveyed areas. This finding agrees with reports of [17]. Likewise, Shortage of feed and feed resources, lack of access to improved breeds, market and credit services were the major dairy development challenges in the Southern-Ethiopia.

Shortage of grazing land was the major challenges of dairy production identified in highland agro-ecology which could be due to the majority of natural pasture areas were being converted to crop production. On the other hand, in the midlands of the study are the sever challenge was inadequate animal feed resources due the shifting of grazing land to crop land that leads shortage of grazing land. Similar report [18] indicated that overgrazing was common due to inadequate use of natural pasture in Sidama Zone, southern Ethiopia.

However, in the lowland agro-ecologies of the study area most severe challenge as discussed by the respondents were animal health problem than shortage of animal feed resources. The current study is in consistent with [19] who reviewed that the prevalence of various animal diseases affects dairy development programs in various scale, depends on ecological zones and management levels, including tick borne diseases, internal and external parasite and infectious diseases.

Table 3. Challenges for dairy cattle production in the study area by agro-ecology

\begin{tabular}{|c|c|c|c|c|}
\hline Challenges & $\begin{array}{c}\text { Lowland }(\mathrm{N}=58) \\
\text { Index }\end{array}$ & $\begin{array}{c}\text { Agro-ecology } \\
\text { Midland (N=50) } \\
\text { Index }\end{array}$ & $\begin{array}{c}\text { Highland }(\mathrm{N}=42) \\
\text { Index }\end{array}$ & $\begin{array}{c}\text { Overall } \\
\text { index mean }\end{array}$ \\
\hline Shortage of land for grazing or forage development & 0.18 & 0.24 & $0.40 *$ & $0.28 *$ \\
\hline Animal health problems & $0.31 *$ & 0.27 & 0.19 & 0.26 \\
\hline Inadequate animal feed resources & 0.21 & $0.29 *$ & 0.21 & 0.24 \\
\hline Inefficient AI services & 0.10 & 0.06 & 0.10 & 0.09 \\
\hline Lack of capital & 0.10 & 0.05 & 0.05 & 0.07 \\
\hline Inadequate extension and training services & 0.08 & 0.06 & 0.04 & 0.06 \\
\hline Milk market linkage problems & 0.03 & 0.05 & 0.01 & 0.03 \\
\hline
\end{tabular}

$\mathrm{N}=$ Number of respondents, Index $=$ sum of [ $4 \times$ number of responses for $1^{\text {st }}$ rank $+3 \times$ number of responses for ${ }^{2 n d}$ rank $+2 \times$ number of responses for $3^{\text {rd }}$ rank $+1 \times$ number of responses for $\left.\left.4^{\text {th }}\right)\right] /\left(4 \times\right.$ total responses for $1^{\text {st }}$ rank $+3 \times$ total responses for $2^{\text {nd }}$ rank $+2 \times$ total responses for $3^{\text {rd }}$ rank +1 $\times$ total responses for $4^{\text {th }}$ rank). *The higher the rank for a given reason, the greater its severity.

\subsubsection{Opportunity of dairy cattle production in the study area}

From the present study, it was known that there were huge opportunities for dairy cattle production in the study areas (Table 4). These are important requirements for sustainable dairy farming. From this result, opportunity of the dairy cattle production ranked next to water access was indigenous knowledge. From this finding, it is concluded that the existence of diversity of dairy and agro-ecologies coupled with diverse flora species rendered the area to have indigenous knowledge. This is consistent with [20] that indicated all rural and nearly half of the urban dwellers are not Orthodox followers, thus no fasting period against dairy products consumption in Gambella. Dairy producers also stated that they have the tendency to continue to work and expand their dairy farming activities. This finding was adjoining with the reports of [19] who reviewed about dairy cattle production and indicated that dairy farm created different opportunity including: large diversity and population of cattle, employment opportunities and service providers.

\subsection{Dairy cattle husbandry and management Practices}

\subsubsection{Feeds and feeding}

The major sources of feeds in the study area were natural pasture, cereal crop residues, and grass hay and crop aftermath. The contribution of these feed resources, however, depends up on the agro-ecology, season, the types of crop produced, and accessibility and production system.

In the lowland areas among cereal crop residues used, maize and sorghum Stover is the major feed resources. While teff, wheat and barley straw are important feed resources in the midland and highland areas (Table 5). Feed resources obtained in the present study is similar with the results of [7] who reported the main feed resource for local cattle be grazing of natural pasture and crop aftermaths and crop residues in Tigray regional state, Ethiopia.

The feed sources in midland (30\%) from crop residue were greater than that of lowland (25\%) agro-ecology. The 
contribution of natural pasture grazing land was lower because of the delineation of dominant cropland to integrate with livestock and the grazing lands had been given to the organized landless youths living around the area. Low altitude agro-ecologies had still used natural pasture as a major feed source of dairy animals. Similar reports presented by [21] in the highlands and midlands, various food crop residues including cereals crop residues are providing considerable quantity feed.

Table 4. Rank of opportunity for dairy cattle production practices by agro-ecology

\begin{tabular}{|c|c|c|c|c|}
\hline \multirow{3}{*}{ Opportunity } & \multicolumn{3}{|c|}{ Agro-ecology } & \multirow{3}{*}{$\begin{array}{l}\text { Overall index } \\
\text { mean }\end{array}$} \\
\hline & $\begin{array}{l}\text { Lowland } \\
(\mathrm{N}=58)\end{array}$ & $\begin{array}{l}\text { Midland } \\
(\mathrm{N}=50)\end{array}$ & $\begin{array}{l}\text { Highland } \\
(\mathrm{N}=42)\end{array}$ & \\
\hline & Index & Index & Index & \\
\hline Availability of water throughout the year & $0.30 *$ & 0.31 & 0.31 & $0.31 *$ \\
\hline Indigenous knowledge & 0.26 & 0.16 & 0.14 & 0.19 \\
\hline $\begin{array}{l}\text { Absence of cultural or religious prohibition of dairy } \\
\text { products consumption }\end{array}$ & 0.07 & $0.23 *$ & $0.20 *$ & 0.17 \\
\hline High demand of dairy products & 0.07 & 0.16 & 0.25 & 0.16 \\
\hline Large diversity and population of cattle & 0.15 & 0.09 & 0.00 & 0.08 \\
\hline Relatively cheap farm labor & 0.04 & 0.04 & 0.10 & 0.06 \\
\hline Service providers & 0.03 & 0.004 & 0.00 & 0.01 \\
\hline
\end{tabular}

$\mathrm{N}=$ Number of respondents, Index $=$ sum of $\left[\left(4 \times\right.\right.$ number of responses for $1^{\text {st }}$ rank $+3 \times$ number of responses for ${ }^{2 n d}$ rank $+2 \times$ number of responses for $3^{\text {rd }}$ rank $+1 \times$ number of responses for $\left.\left.4^{\text {th }}\right)\right] /\left(4 \times\right.$ total responses for $1^{\text {st }}$ rank $+3 \times$ total responses for $2^{\text {nd }}$ rank $+2 \times$ total responses for $3^{\text {rd }}$ rank +1 $\times$ total responses for $4^{\text {th }}$ rank). *The higher the rank for a given reason, the greater its prospect.

Table 5. Major feed sources and feeding systems identified in the Bako district

\begin{tabular}{|c|c|c|c|c|c|}
\hline \multirow{3}{*}{\multicolumn{2}{|c|}{ Feed sources }} & \multicolumn{4}{|c|}{ Agro-ecology } \\
\hline & & Lowland (N=58) & Midland (N=50) & Highland $(\mathrm{N}=42)$ & Overall $(\mathrm{N}=150)$ \\
\hline & & $\%$ & $\%$ & $\%$ & $\%$ \\
\hline \multicolumn{2}{|c|}{ Grazing natural pasture } & 44.8 & 38.0 & 40.5 & 41.3 \\
\hline \multicolumn{2}{|c|}{ Cereal crop residues } & 25.9 & 30.0 & 16.7 & 24.7 \\
\hline \multicolumn{2}{|c|}{ Crop aftermath/stubble grazing } & 12.1 & 18.0 & 26.2 & 18.0 \\
\hline \multicolumn{2}{|c|}{ Hay } & 12.1 & 14.0 & 16.7 & 14.0 \\
\hline \multicolumn{2}{|c|}{ Concentrates } & 5.2 & - & - & 2.0 \\
\hline \multicolumn{6}{|c|}{ Feeding systems } \\
\hline \multicolumn{2}{|c|}{ Free/continues grazing } & 82.8 & 82 & 88.1 & 84.0 \\
\hline \multicolumn{2}{|c|}{ Grazing with supplementary feeding. } & 12.1 & 12 & 7.1 & 10.7 \\
\hline \multicolumn{2}{|c|}{ Zero grazing or cut and carry } & 5.2 & 6 & 4.8 & 5.3 \\
\hline \multicolumn{6}{|c|}{ Ways of feeding systems } \\
\hline \multirow{2}{*}{ Group feeding } & Yes & 81 & 82 & 26.2 & 66 \\
\hline & No & 19 & 18 & 73.8 & 34 \\
\hline \multicolumn{6}{|c|}{ Group feeding based on } \\
\hline \multicolumn{2}{|c|}{ Age } & 19.6 & - & - & 6.0 \\
\hline \multicolumn{2}{|c|}{ Sex } & 28.3 & 36.6 & 90.9 & 26.0 \\
\hline \multicolumn{2}{|c|}{ Breed } & 6.5 & - & - & 2.0 \\
\hline \multicolumn{2}{|c|}{ Reproduction status } & 45.7 & 63.4 & 9.1 & 32.0 \\
\hline
\end{tabular}

$\mathrm{N}=$ Number of respondents

\subsubsection{Housing and waste management practices}

Dairy animals are often housed at night and the type of housing provided varied depending upon the classes of dairy animals, agro-ecology and physiological stage of dairy animals. Out of all respondents' interviewed, the majority of the farmers $(69 \%)$ keep in enclosed barn for indigenous dairy cattle, while some keep them (4\%) in the farmer's house mixed with people, (2\%) separated room in the family house for crossbred. The rest of the respondents herded in tem- 
porary mobile corrals Dallaa on crop fields to allow them to drop manure and urine in order to fertilize farmlands. The experience from different production systems shows that manure is an important input for crop production and for nutrient recycling in the study areas. Moreover, manure is an alternative source of energy (in the form biogas) this was not observed in the study areas.

\subsubsection{Breeding Practices}

As shown in Table 6, mating type was presented to the sampled households. Accordingly, in lowland agro-ecology $94.8 \%$ of the respondents practice natural mating whereas, all respondents practice natural mating in midland and highland agro-ecology of the study areas. In this case, bulls are commonly run with cows all year round and breeding is thus uncontrolled. As cattle herders do not use control breeding, the reproduction of their cattle is primarily regulated by seasonal feed availability.

The shortage of AI services and unwillingness of technicians were the major problems stated in the area. Bulls can be used for two main types of natural mating, either free mating in the grazing or controlled mating. In free mating system, heat detection is carried out by the bull and cows in heat are usually mated several times during each heat period. This result is similar with the report of [22] that, $89.5 \%$ of smallholders' farmers use natural mating and AI services was not accessible at all in Southern, Ethiopia.

Table 6. Breeding methods, selection criteria of breeding bull and dairy cattle (\%)

\begin{tabular}{|c|c|c|c|c|c|}
\hline \multirow{3}{*}{ Variables } & \multirow{3}{*}{ Group } & \multicolumn{4}{|c|}{ Agro-ecology } \\
\hline & & $\begin{array}{l}\text { Lowland } \\
(\mathrm{N}=58)\end{array}$ & $\begin{array}{l}\text { Midland } \\
(\mathrm{N}=50)\end{array}$ & $\begin{array}{l}\text { Highland } \\
(\mathrm{N}=42)\end{array}$ & Overall $(\mathrm{N}=150)$ \\
\hline & & $\%$ & $\%$ & $\%$ & $\%$ \\
\hline \multirow{2}{*}{ Breeding practiced } & Bull (natural mating) & 94.8 & 100 & 100 & 98.0 \\
\hline & AI used & 5.2 & - & - & 2.0 \\
\hline \multirow{2}{*}{$\begin{array}{l}\text { Having own breed- } \\
\text { ing bull }\end{array}$} & Yes & 51.7 & 44 & 38.1 & 45.3 \\
\hline & No & 48.3 & 56 & 61.9 & 54.7 \\
\hline \multirow{3}{*}{$\begin{array}{l}\text { If absent sources of } \\
\text { bull }\end{array}$} & Neighbours bull & 60.7 & 80.6 & 84.6 & 42.7 \\
\hline & Communal bull & 35.7 & 19.4 & 15.4 & 13.3 \\
\hline & Artificial insemination & 3.6 & - & - & 0.7 \\
\hline \multirow{3}{*}{$\begin{array}{l}\text { Selection criteria of } \\
\text { breeding bull }\end{array}$} & Large body size & 50 & 48 & 33.3 & 44.0 \\
\hline & Temperament & 26.8 & 14 & 31 & 23.3 \\
\hline & Normal Testicle & 23.2 & 38 & 35.7 & 31.3 \\
\hline \multirow{4}{*}{$\begin{array}{l}\text { Selection criteria of } \\
\text { dairy cow/heifer }\end{array}$} & Large body size & 41.4 & 30 & 7.1 & 28.0 \\
\hline & Present and equal teats & 22.4 & 48 & 23 & 40.0 \\
\hline & Large udder and teat & 19 & 14 & 6 & 16.0 \\
\hline & $\begin{array}{l}\text { Milk production background } \\
\text { (history) }\end{array}$ & 17.2 & 8 & 10 & 16.0 \\
\hline
\end{tabular}

$\mathrm{N}=$ Number of respondents

\subsubsection{Water resources and watering practices}

There are different sources of water in the district. The main sources of water classified in the current study areas were rivers, spring water and hand dug well. However the availability of these water resources depends on the season and distance from the household. Availability of water also affects voluntary feed intake [23]. The majority (80\%) of the households achieve water from rivers, whereas (12\%) and (8\%) from well/bore holes and spring water respectively.

About (70.7\%) of the dairy producers water their dairy animals ad-lib, 26.7 and $2.7 \%$ water two times per day and once per two day respectively. Generally, the frequency of watering to their dairy animals varied based on the agro-ecology, season of the year, the age structure of the herd, physiological stages of the animals and access to water.

\subsubsection{Health problems}

Diseases in dairy animals affect reproduction, milk production, milk quality and cause mortality and morbidity. From this figure trypanosomosis was cited as the most important disease in the area. Poor animal health service and lack of improved management are the major constraints for dairy development in Ethiopia, which caused poor performance 
across the production systems [24]. The present study is consistent with [25] report that the major disease in the rural highland system of Fogera includes trypanosomosis. Out of all household interviewed (58\%) used taking to traditional healer, (27.7\%) taking to private clinic and while (17.3\%) taking to government clinic to treat their dairy animals.

As a result, a wealth of indigenous knowledge in animal health care is the major means of treating animals in the surveyed areas. Traditionally women drench herbs to sick animals as the male member of the household is responsible in collecting the herbs from the field especially around rivers. During group discussion indicated that there is no regular visit occurred by veterinarians followed by long distance to the veterinary clinics those things aggravate the loss of animals due to disease.

Table 7. Major dairy animals' health problems in the area (\%)

\begin{tabular}{ccccc}
\hline \multirow{2}{*}{$\begin{array}{c}\text { Major health problems of dairy } \\
\text { cattle }\end{array}$} & Lowland (N=58) & Midland (N=50) & Highland (N=42) & Overall (N=150) \\
& $\%$ & $\%$ & $\%$ & 27.3 \\
\hline Trypanosomosis & 43.1 & 6 & 31 & 18.7 \\
Pasteurollosis & 6.9 & 22 & 9.5 & 13.3 \\
Blackleg & 13.8 & 16 & 28.6 & 20.0 \\
Leeches & - & 36 & - & 20.7 \\
\hline
\end{tabular}

$\mathrm{N}=$ Number of respondents

\subsection{Milk production, utilization and reproduction performance}

\subsubsection{Milk production performance}

The first and most important purpose of dairy cattle production is to provide milk for family use and sale. However, milk yield of indigenous cattle is very low. In Table 8 below, productive performance of local and crossbred of dairy animals in the study area were shown.

Milk yield on average basis of the LL was calculated without taking into account the initial low production, peak yield and the declining in production in the last phase of the lactation. The overall mean of daily milk off take (DMO) of indigenous dairy cows were reported by respondents as $1.7 \pm 0.03$ and $1.5 \pm 0.01 \mathrm{~L} /$ day/cow during wet and dry seasons respectively.

The study revealed that the average DMO $( \pm \mathrm{SE})$ of local cows in each agro-ecology were not different. However, there was a seasonal variation; which means the average DMO during wet season is greater than average DMO gain during dry season. The current study is consistent with the report of [22] that indicates variation in milk yield between seasons in the Southern Region, Ethiopia.

The average $( \pm \mathrm{SE})$ volume of milk produced/day/cow in the present study (1.6 \pm 0.03 liters) is more or less similar to [26], with the value of $1.7 \pm 0.1 \mathrm{~L} /$ day/cow from local breed indigenous Arsi cows. Indigenous breed of cows are generally considered as low milk producers. However, they were the major source of milk in the study area. The average LL of current study for local dairy cows is similarly reported by [31] which was 7.6 \pm 0.1 months in Gindeberet of West Showa Zone, Oromia Regional State. But it is lower than 9.5 months reported by [27] for local cows in the East Showa zone of Oromia region. Generally, it was reported that the average DMO per cow for local breeds at country level is about 1.4 $\mathrm{L}$ whereas the average LL was estimated to be about six months [5].

The average MO (SE) produced L/day/cow of crossbred in the current study is $6.5 \pm 0.3$ and $5 \pm 0.6$ during wet and dry seasons respectively. The current result for crossbred is lower than the finding of [28] who reported an average DMO $( \pm \mathrm{SE})$ of 7.3 $\pm 4.6 \mathrm{~L} / \mathrm{day} / \mathrm{cow}$ at Debremarkos of Amhara Regional State, Ethiopia. The difference might be almost certainly related to poor management practices. The average LL $( \pm \mathrm{SE})$ for crossbred was $9.00 \pm 0.587$ months and result was comparable with the findings of [29] who reported that the average LL of crossbreds of dairy cows at Jimma town Oromia Regional State was $9.13 \pm 1.9$ months.

In general dairy animals in the study area depends mostly on the management of the herder, may the herder prolong the lactation length for the sake of continues milk production or dry off the dam at early stage for the purpose of breeding the cows.

\subsubsection{Milk utilization}

Consumption pattern of milk and milk products produced at home varies depending upon the amount of milk produced per household, and access of market, season of the year, and fasting period. In Table 9 shown below, the milk utilization form of the households was prioritized. The figure shows that the majority of the respondents were used for 
processing, home consumption, sale and calf feeding in their descending order. However, dairy animals produced in the area are small scale; the primary objective of keeping dairy cows in the study area was for milk production to transform various milk products. Milk is used in a variety of ways in the study area: as fresh liquid milk, fermented milk (Ergo), butter, cottage cheese (Ayib), buttermilk (Arrera) and whey (Aguat). The importance of milk in the diet of Ethiopians differs according to the farming system and the socio-cultural setup [30]. In addition, during group discussion they exposed that, the consumption pattern of milk and milk products produced at home varies depending upon the amount of milk produced per household, dairy production system, market access, season of the year and fasting period.

Table 8. Mean and standard errors of productive parameters of local and crossbreds of dairy cattle

\begin{tabular}{|c|c|c|c|c|}
\hline \multirow{3}{*}{ Variables } & \multicolumn{4}{|c|}{ Agro-ecology } \\
\hline & Lowland $(\mathrm{N}=58)$ & Midland $(\mathrm{N}=50)$ & Highland $(\mathrm{N}=42)$ & Overall Mean $(\mathrm{N}=150)$ \\
\hline & Mean \pm SE & Mean \pm SE & Mean \pm SE & Mean \pm SE \\
\hline \multicolumn{5}{|l|}{ Local breeds } \\
\hline Lactation length (months) & $7.6 \pm 0.2$ & $6.9 \pm 0.14$ & $7.2 \pm 0.17$ & $7.3 \pm 0.1$ \\
\hline Milk yield during wet season (lit/day/cow) & $1.7 \pm 0.04$ & $1.6 \pm 0.05$ & $1.7 \pm 0.04$ & $1.7 \pm 0.03$ \\
\hline Milk yield during dry season (lit/day/cow) & $1.5 \pm 0.06$ & $1.47 \pm 0.06$ & $1.5 \pm 0.06$ & $1.5 \pm 0.03$ \\
\hline \multicolumn{5}{|l|}{ Crossbreeds } \\
\hline Lactation length (months) & $9 \pm 0.6$ & - & - & $9 \pm 0.6$ \\
\hline Milk yield during wet season (lit/day/cow) & $6.5 \pm 0.3$ & - & - & $6.5 \pm 0.3$ \\
\hline Milk yield during dry season (lit/day/cow) & $5 \pm 0.6$ & - & - & $5.00 \pm 0.6$ \\
\hline
\end{tabular}

$\mathrm{N}=$ Number of respondents, $\mathrm{SE}=$ Standard Error

Table 9. Milk utilization ranked by households in the study area

\begin{tabular}{|c|c|c|c|c|c|}
\hline \multirow{2}{*}{ Milk utilization form } & \multicolumn{4}{|c|}{ Ranked (no of responses) (N=150) } & \multirow{2}{*}{ Overall index Mean } \\
\hline & 1 & 2 & 3 & 4 & \\
\hline For processing & 87 & 120 & - & 3 & 0.47 \\
\hline Home consumption & 60 & - & 40 & - & 0.21 \\
\hline Calf feeding & - & 30 & 110 & - & 0.21 \\
\hline For sale & 3 & - & - & 147 & 0.11 \\
\hline
\end{tabular}

$\mathrm{N}=$ Number of respondents

\subsubsection{Reproductive performances}

As represented in Table 10, the parameters for reproductive performance such as age at first service (AFS), age at first calving (AFC) and Calving interval (CI) of both local and crossbreeds cows were shown. The average AFS and AFC is more different between the agro-ecology; the AFS and AFC in highland is greater than that of lowland but that of midland and lowland is more or less similar for local dairy cows. The supposed reasons for the shorter AFS in the lowland and midland might be for the availability of pastureland while compared with highland in the study area.

The overall average AFS identified for local and crossbreds heifers were $44.45 \pm 0.167$ and $29.33 \pm 0.33$ months respectively. The current result reported for local cows was agreement with the report of [31] who reported $45.3 \pm 0.5$ at Abuna Gindeberet Oromia Regional State.

The overall average AFC for local and crossbreds in the study area were; $54.5 \pm 0.2$ and $38.4 \pm 0.5$ months respectively. The result of this study for local cow was higher than the value (50.6 \pm 6.9$)$ reported by [29] in Dandi district of West Shoa Zone. However, it was almost similar with the value (53.5 \pm 7.7 months) reported by [32] in Bure district of Amhara Regional State. The longer age at first calving in the study district might be due to feed shortage and management status of dairy cows in the area. The overall average CI for both local and crossbreds in the area were; $16.7 \pm 0.04$ and $14.3 \pm 0.8$ months respectively.

The current finding was lower than the finding of [31] reported 20.9 \pm 0.2 months for calving interval of local cows and 17.7 \pm 1.23 for crossbreds at Abuna Gindeberet Oromia Regional State. Similarly, the reported average CI in the study area were less than reported the value (24.9 months) [33] who reported for indigenous breed in North Showa, 
Oromia regional state. However, the current result is comparable with the reported [34] that, the mean age of CI for local cow was 16.8 months in Borana zone, Oromia Regional State. But the difference could be explained mainly by environmental factors such as nutritional management.

Table 10. Mean and standard errors of reproductive parameters of local and crossbreds of dairy cattle

\begin{tabular}{|c|c|c|c|c|}
\hline \multirow{3}{*}{ Variables } & \multicolumn{4}{|c|}{ Agro-ecology } \\
\hline & Lowland (N=58) & Midland $(\mathrm{N}=50)$ & Highland (N=42) & Overall Mean $(\mathrm{N}=150)$ \\
\hline & Mean \pm SE & Mean \pm SE & Mean \pm SE & Mean \pm SE \\
\hline \multicolumn{5}{|l|}{ Local breeds } \\
\hline Age at first services (months) & $43.8 \pm 0.2$ & $43.8 \pm 0.2$ & $46.1 \pm 0.3$ & $44.5 \pm 0.2$ \\
\hline Age at first calving (months) & $53.8 \pm 0.2$ & $53.8 \pm 0.2$ & $56.2 \pm 0.3$ & $54.5 \pm 0.2$ \\
\hline Calving interval (months) & $16.6 \pm 0.1$ & $16.7 \pm 0.1$ & $16.66 \pm 0.1$ & $16.7 \pm 0.03$ \\
\hline \multicolumn{5}{|l|}{ Crossbreeds } \\
\hline Age at first services (months) & $29.3 \pm 0.3$ & - & - & $29.3 \pm 0.3$ \\
\hline Age at first calving (months) & $38.4 \pm 0.5$ & - & - & $38.4 \pm 0.5$ \\
\hline Calving interval (months) & $14.3 \pm 0.8$ & - & - & $14.3 \pm 0.8$ \\
\hline
\end{tabular}

$\mathrm{N}=$ Number of respondents, $\mathrm{SE}=$ Standard Error

\subsection{Milk and milk products handling practices}

Hygienic milk production is important and should take into account the sanitation of the barn, personnel involved in milking and the utensils used to collect and store milk. Milk and milk products handling utensils, purpose and plants used for smoking followed in the study area were given in Table 11. The material used for milking, storage/fermentation and processing are different and diversified in the study area. The study revealed that the majority of the respondents used plastic container for milk and milk products handling.

As other small holder milk producers in many parts of the country, milk producers of the area were using traditionally prepared and plastic materials to handle and store milk and milk products. As observed during survey period farmers in the study area were using locally made traditional equipments for milk handling purpose. Among them, "Okkote", and "Qabee" were used "Okkote"/clay pot for milk storage. "Kubaya"/plastic sources, and "Cilfaa" /stainless steel sources were used for butter handling in the study areas. This finding is similar with the report of [35] that dairy farmers in North western Ethiopian high lands were using different milk utensils for collecting, storing and handling of milk and milk products. The same is true that $[4,36]$ also found milk producers using traditional materials for milk handling, storing and churning in their respective study areas in Amhara regional state.

All of the respondents in the surveyed areas of three agro-ecology practice smoking of milk utensils for different purposes. The major purpose of smoking milk vessels reported by the respondents was for good flavor (91.3\%) and for longer shelf life of the products (8.7\%). Smoking of milk and milk products utensils was a common practice and milk producers had different reasons for smoking these utensils in the present study area. The major reasons were: for good flavor of the product, for longer shelf life of the products. The finding of the current study was in line with the report of [26] stated that nearly all inhabitants of in Mid Rift Valley of Ethiopia were smoked milk vessels as a traditional preservative method to improve the taste and quality of milk and milk products. In the same way practices of milk utensils smoking was also reported by [32, 36, 37] in Bure, Meiso and Metema districts respectively.

The plants that are used for cleaning and smoking milk vessels are shown in table below. All the households practice washing the milk utensils used for milking and storing of milk and milk products. The most common product/plant used for smoking milk utensils in the area were, "Xaaxessaa" (Rhus natalensis) (32.0\%), "Dabaqqaa” (Terminalia laxiflora) (22.7\%), "Kusaayee" (Ocimum hardiense) (20.7\%), "Ejersa” (Olea africana) (17.3\%) and the rest used "Qadiidaa" (Rhamnus staddo). From these plants according to the farmers explanation "Kusayee" (Ocimum hardiense) is used also for cleaning purpose while all the rest plants used for smoking purposes. The current finding is in line with the findings of [38, 39] in eastern Wollega, West shoa, and central highlands of Ethiopia, respectively who reported "Ejersa" (Olea africana) is commonly used for smoking milk equipments. This result also agreed with the result of [40] reported that milking utensils were smoked with different aroma producing plants like Olea africana and Juniperous procera. Based on agro-ecology the type of smoking plants are not similar this might be due to different environmental requirement for plant species. 
Table 11. Milk and milk products handling utensils, purpose and plants used for smoking (\%)

\begin{tabular}{|c|c|c|c|c|}
\hline \multirow{2}{*}{ Variables } & \multicolumn{3}{|c|}{ Agro-ecology } & \multirow[b]{2}{*}{ Overall $(\mathrm{N}=150)$} \\
\hline & Lowland (N=58) & Midland $(\mathrm{N}=50)$ & Highland $(\mathrm{N}=42)$ & \\
\hline & $\%$ & $\%$ & $\%$ & $\%$ \\
\hline Clay pot & 17.2 & 56.0 & 9.5 & 28.0 \\
\hline plastic container & 39.7 & 30.0 & 28.6 & 33.3 \\
\hline Bottle Gourd & 10.3 & - & 57.1 & 20.0 \\
\hline Stainless steel & 32.8 & 14.0 & 4.8 & 18.7 \\
\hline \multicolumn{5}{|l|}{ Purpose of smoking } \\
\hline For good flavour & 79.3 & 100.0 & 97.6 & 91.3 \\
\hline For longer shelf life of the products & 20.7 & - & 2.4 & 8.7 \\
\hline \multicolumn{5}{|l|}{ Products/plants used for smoking and cleaning } \\
\hline (VN. Dabaka) (SN. Terminalia Laxiflora) & 58.6 & - & - & 22.7 \\
\hline (VN. Kusaye) (SN. Ocimum hardiense) & 41.4 & 6.0 & 9.5 & 20.7 \\
\hline (VN. Ejersa) (SN. Olea Africana) & - & 38.0 & 16.7 & 17.3 \\
\hline (VN. Xaxesa) (SN. Rhus natalensis) & - & 56.0 & 47.6 & 32.0 \\
\hline (VN. Qadida) (SN. Rhamnus Staddo) & - & - & 26.2 & 7.3 \\
\hline
\end{tabular}

$\mathrm{N}=$ Number of respondents $\mathrm{VN}=$ Vernacular Name, $\mathrm{SN}=$ Scientific Name

\subsection{Marketing systems of milk and milk products}

According to the respondents' opinion during RMA observed, milk and butter were sold in the study area. The results in the current study are comparable with the report [41] who reported that selling of butter is a common practice in Dangila district Amhara Regional State. In the present study, farmers practice informal marketing system where they sell their milk and milk products.

According to the respondents, the reported sale of outlets for butter was open local market (62.7\%), farm gate (21.3\%) and delivery to buyer (16.0\%). The reason for choice of outlets reported includes good prices $(74.7 \%)$, short distances (14.0\%), reliable customers (6.7\%) and the rest mode of payment. The reported buyer type known in the areas were consumers (53.3\%) and traders (46.7\%) while the reported modes of payment were cash.

Table 12. Milk and butter sales outlets, choice of outlets, buyer type and mode of payment (\%)

\begin{tabular}{|c|c|c|c|c|c|}
\hline Products & Groups & $\begin{array}{c}\text { Lowland }(\mathrm{N}=58) \\
\%\end{array}$ & $\begin{array}{c}\text { Agro-ecology } \\
\text { Midland (N=50) } \\
\%\end{array}$ & $\begin{array}{c}\text { Highland }(\mathrm{N}=42) \\
\%\end{array}$ & $\begin{array}{c}\text { Overall }(\mathrm{N}=150) \\
\%\end{array}$ \\
\hline \multirow{8}{*}{ Raw milk } & Sales outlets of butter & & & & \\
\hline & Delivery to buyer & 100 & 0 & 0 & 2 \\
\hline & Reason for choice of outlet & & & & \\
\hline & Reliable customer & 100 & 0 & 0 & 2 \\
\hline & Buyer type & & & & \\
\hline & Trader/Retailers & 100 & 0 & 0 & 2 \\
\hline & Mode of payment & & & & \\
\hline & Cash & 100 & 0 & 0 & 2 \\
\hline \multirow{14}{*}{ Butter } & Sales outlets of butter & & & & \\
\hline & Farm gate & 17.2 & 12.0 & 38.1 & 21.3 \\
\hline & Open local market & 79.3 & 68.0 & 33.3 & 62.7 \\
\hline & Delivery to buyer & 3.4 & 20.0 & 28.6 & 16.0 \\
\hline & Reason for choice of outlet & & & & \\
\hline & Good price & 75.9 & 80.0 & 66.7 & 74.7 \\
\hline & Short distances & 13.8 & 4.0 & 26.2 & 14.0 \\
\hline & Reliable customer & 5.2 & 10.0 & 4.8 & 6.7 \\
\hline & Mode of payment & 5.2 & 6.0 & 2.4 & 4.7 \\
\hline & Buyer type & & & & \\
\hline & Consumer & 62.1 & 44.0 & 52.4 & 53.3 \\
\hline & Trader/Retailers & 37.9 & 56.0 & 47.6 & 46.7 \\
\hline & Mode of payment & & & & \\
\hline & Cash & 100 & 100 & 100 & 100 \\
\hline
\end{tabular}

$\mathrm{N}=$ Number of respondents 


\section{Conclusion}

Dairy cattle production in the area is not improved, as only few crossbreeds prevails, shortage of grazing lands, health problems and lack of working capital are some of the major reason for poor performance of dairy cattle production and cause a huge loss of production and productivity of dairy cattle in the area.

\section{Acknowledgement}

The authors acknowledged the Ministry of Agriculture and Livestock resources for financing the research, the district administration and the agricultural extension workers and experts for their willingness to participate in the study and provide valuable information.

\section{References}

[1] CSA (Central Statistical Agency). (2016/17). Federal democratic republic of Ethiopia: Agricultural sample survey 2016/17 [2009 E.C.], volume-2: Report on livestock and livestock characteristics (private peasant holdings). Statistical bulletin-585, April 2017, Addis Ababa, Ethiopia.

[2] Zegeye, Y. (2003). Challenges and opportunities of livestock marketing in Ethiopia. In: Proceeding of the $10^{\text {th }}$ Annual Conference of Ethiopian Society of Animal Production (ESAP) 22-24 August 2002. ESAP, Addis Ababa, Ethiopia. Pp. 47-54.

[3] MoARD (Ministry of Agriculture and Rural Development). (2004). Market-Oriented Development Master Plan.

[4] Belete, A. Azage, T. Fekadu, B., and Berhanu, G. (2010). Cattle milk and meat production and marketing systems and opportunities for market-orientation in Fogera woreda, Amhara region, Ethiopia. Improving Productivity and Market Success (IPMS), Ethiopian Farmers Project Working Paper19. ILRI (International Livestock Research Institute), Nairobi, BTWANRO (Bako Tibe Woreda Agriculture and Natural Resources Office), 2018.

[5] CSA (Central Statistical Agency). (2015/2016). Federal democratic republic of Ethiopia: Key findings of the 2015/2016 (2008 E.C) agricultural sample surveys: Country summary, July, 2016, Addis Ababa, Ethiopia.

[6] Ministry of Agriculture (MoA). (2012). Livestock growth strategy and action. Draft discussion paper. Addis Ababa: MoA. (Amharic version).

[7] Tsadkan, Z. (2012). Studies on cattle milk production, processing and marketing system in Enderta district Tigray Regional state, Ethiopia. MSc. Thesis, University of Addis Abab, Debre-zeit, Ethiopia.

[8] CSA (Central Statistics Agency). (2007). Summery and Statistical Report of 2007 Population and Housing Census of Ethiopia: Population size by age and sex [internet] [cited 2011 Jan 18]. Available from: http://www.csa.gov.et.

[9] BTWANRO (Bako Tibe Woreda Agriculture and Natural Resources Office). (2018).

[10] Arsham, H. (2007). Business statistical decision science and systems stimulation Merrie School of business Charles at Mount Royal, Baltimore, Maryland, 2120, University of Baltimore, UAS, p. 100.

[11] Musa, L. M. A., K. J. Peters, and M. K. A. Ahmed. (2006). On farm characterization of Butana and Kenana cattle breed production systems in Sudan. Livest. Res. for Rural Develop, 18(12). 2006.

[12] Bainesagn, W. (2016). Smallholder Cattle Production Systems and Husbandry Management in West Showa Zone of Oromia Regional State, Central Ethiopia. World scientific News. WSN. 53(3). 178-188.

[13] IBC (Institute of Biodiversity Conservation). (2004). The state of Ethiopia's Farm Animal Genetic Resources: A contribution to the first report on the state of the world's animal genetic resources. May 2004, Addis Ababa, Ethiopia.

[14] CSA (Central Statistical Agency). (2017). Federal democratic republic of Ethiopia: Agricultural sample survey 2016/17 [2009 E.C.], volume-2: Report on livestock and livestock characteristics (private peasant holdings). Statistical bulletin-585, April 2017, Addis Ababa, Ethiopia.

[15] Bultossa Terefe, Willy and Adeba Gemechu. (2016). Determinants of market participation and financial profitability of smallholder dairy farming. The case of Bako Tibe, West showa, Ethiopia. Trends Agric. Econ., 9: 29-44. Kenya. Pp. 65.

[16] Abebe, T. and Markos, T. (2009). Milk Quality Control. Technical Bulletin No. 2. International Center for Agricultural Research in the Dry Areas (ICARDA), University of Aleppo.

[17] Terefe, T., Oosting, S. J., and Jan van der, L. (2016). Smallholder Dairy Production: Analysis of Development Constraints in the Dairy Value Chain of Southern-Ethiopia.

[18] Tsegay Lijalem, Agegnew Asefa, and Ashenafi Sharo. (2015). Challenges and Opportunities of Dairy Cattle Production in Selected Districts of Sidama Zone, Southern Ethiopia. Food Science and Quality Management. Vol. 44.

[19] Tadesse Guadu and Mengistie Abebaw. (2016). Challenges, Opportunities and Prospects of Dairy Farming in Ethiopia: A Review. Department of Veterinary Epidemiology and Public Health, Faculty of Veterinary Medicine, University of Gondar, World Journal of Dairy \& Food Sciences, 11(1): 01-09.

[20] Gatwetch, T. (2012). Dairy production, processing and market system: A case study of Gambella, south west Ethiopia. M.Sc. 
Thesis Addis Ababa University, Debrezeit, Ethiopia.

[21] Teklay, A. (2008). Assessment of the feeding systems and feed resources of dairy cattle in Lemu-Bilbilo Wereda dairy products processing cooperatives, Arsi Zone of Oromia Regional State, Ethiopia. MSc. Thesis, University of Addis Abab, Debre-zeit, Ethiopia.

[22] Alemayehu, A. and Oosting, S. (2016). Smallholder Dairy Production in Mixed Farming Systems of Southern Ethiopia: Constraints and Options for Intervention. World Journal of Dairy \& Food Sciences, 11(1): 62-79.

[23] Coppock, D. L. (1994). The Boran Pleatue of Southern Ethiopia: Synthesis of Pastoral Research, Development and Change 1980-91. ILCA systems study. No.5. ILCA, Addis Ababa, Ethiopia. P. 393.

[24] Ibrahim, H. and E. Olaloku. (2002). Improving cattle for milk, meat and traction. ILRI, manual ILRI (International Livestock).

[25] Azage, T., Berhanu, G., and Dirk, H. (2013). Smallholder dairy production and marketing systems in Ethiopia. IPMS experiences and opportunities for market-oriented development. Improving Productivity and Market Success of Ethiopian Farmers Project (IPMS) International Livestock Research Institute (ILRI), Addis Ababa, Ethiopia.

[26] Fikrineh Negash, Estefanos Tadesse, Esayas Aseffa, Chali Yimamu, and Feyisa Hundessa. (2012). Production, handling, processing, utilization and marketing of milk in the Mid Rift Valley of Ethiopia. Livestock Research for Rural Development, 24(9).

[27] Lemma, F., Fikadu, B., and P. B. Hegde. (2005). Traditional milk and milk products handling practices and preservation methods in three districts of East Shoa Zone of Oromia. In: Proceedings of the 12th Annual conference of the Ethiopian Society of Animal Production (ESAP) held in Addis Ababa, Ethiopia, August 12-14, 2004. Addis Ababa, Ethiopia. Pp. 77-84.

[28] Zemenu, Y., Mekonen, H., Kelay, B., and Bimrew, A. (2014). Characterization of dairy cattle production systems in Debremarkos district, Amhara Regional State, Ethiopia. Pacesetter J. Agric. Sci. Res., 2(4): 42-51.

[29] Belay, D. (2012). Productive and Reproductive Performance of Zebu X Holstein-Friesian Crossbred Dairy Cows in Jimma Town, Oromia, Ethiopia. Global Veterinaria, 8(1): 67-72, 2012.

[30] Abebe Bereda, Mitiku Eshetu, and Zelalem Yilma. (2014). Heifer International, East Africa Dairy Development, Country Program Mobilization Coordination Office, Addis Ababa, Ethiopia.

[31] Bayissa Amenu. (2017). Assessment of Productive and Reproductive Performance of Dairy Cows in Gindeberet and Abuna Gindeberet Districts of West Shoa Zone, Oromia Regional State, Ethiopia. Journal of Biology, Agriculture and Healthcare. Vol.7, No.10.

[32] Adebabay Kebede. (2009). Characterization of milk production systems, marketing and on-farm evaluation of the effect of feed supplementation on milk yield and milk composition of cows at Bure district, Ethiopia. MSc Thesis. Bahir Dar University, Ethiopia.

[33] Mulugeta, A. and Belayeneh, A. (2013). Reproductive and lactation performances of dairy cows in Chacha Town and nearby selected kebeles, North Shoa Zone, Amhara Region, Ethiopia. World J. Agric. Sci., 1(1): 8-17.

[34] Dejene Takele. (2014). Assessment of dairy cattle husbandry and breeding management practices of lowland and mid-highland agro-ecologies of Borana zone. Animal and Veterinary Sciences, 2(3): 62-69.

[35] Ayenew, Y., Awuringer, M., Tegene, A., and Zollistsch, W. (2009). Handling are working of milk in the north western Ethiopian high land livestock research for rural development, volume 21 Article II 97. http/ww/rrdary/ irrd 21/7 ayene 21097htm.

[36] Tesafye, L., Puskur, R., Azage, T., and Hoekstra, D. (2007). Exploring innovation capacity in the Ethiopian dairy systems. Paper presented at IFPRI international conference on Advancing Agriculture in Developing Countries through Knowledge and Innovation, 7-9 April 2008, Addis Ababa, Ethiopia.

[37] Kedija Hussein. (2008). Characterization of milk production system and opportunity for market orientation: A Case Study of Mieso District, Oromia Region, Ethiopia. M.Sc. Thesis. Haramaya University, Ethiopia.

[38] Alganesh Tola. (2002). Traditional Milk and Milk Products Handling Practices and Raw Milk Quality in Eastern Wollega. MSc Thesis Presented to the School of Graduate Studies of Alemaya University, Ethiopia.

[39] Lemma, F. (2004). Assessment of butter quality and butter making efficiency of new churns compared to smallholders' butter making techniques in East Shoa Zone of Oromia. MSc Thesis Presented to the Graduate Studies of Alemaya University, Ethiopia. Pp. 129.

[40] Sintayehu, Y., Azege, T., Fikadu, B., and Birhanu, G. (2008). Dairy production, processing and marketing systems of Shashemene-Dilla area, South Ethiopia. IPMS (Improving Productivity and Market Success) of Ethiopian Farmers Project Working Paper 9. ILRI

[41] Bekele, A., Fekadu, B., and Mitiku, E. (2015). Handling, processing and marketing of cow milk in urban and peri urban area of Dangila Town, Western Amhara Region, Ethiopia. Global J. Food Sci. Technol., 3(3): 159-174. 